\title{
nature
}

\section{Budget blues for US science}

President Bill Clinton's budget request for research falls short of the expectations of the scientific community, which have recently risen to unrealistic levels.

t has become customary for Al Gore, the US Vice-President and the strongest advocate for science and technology in the Clinton administration, to formally present the research portion of the president's annual budget proposal on the first Monday of February. This year not only Gore, but also Jack Lew, the director of the White House Office of Management and Budget, and Harold Varmus, the director of the National Institutes of Health (NIH), decided to give this presentation a miss.

By coincidence or not, the research budget presented on 1 February by Neal Lane, the president's science adviser, was perhaps less satisfying to the science lobby than any other of the Clinton era. Indeed, in his remarks, Lane came close to admitting his own disappointment with a set of proposals that would, if approved by Congress in their current form, actually see total research and development investment by the federal government fall during fiscal year 2000, which begins this October (see Nature 397,377; 1999).

The fall results from sharp reductions in spending on development and testing of military equipment; modest increases are proposed for civilian research, including an apparently generous 8 per cent rise for the National Science Foundation (NSF), which funds most non-biomedical research in US universities, and a much-decried 2 per cent increase for NIH. Important science programmes at other agencies, such as the Department of Energy (DoE) and NASA, generally get nothing more than the expected inflation rate of 2 per cent.

The figures themselves are not untypical of the budgets presented by Clinton during his first term. What has disappointed the science lobbyists this time is the fact that the national kitty is full (the overall budget now being in healthy surplus) and that rhetoric in favour of expanding the research base has been in full flood, not least from the president himself. During 1998, both houses of Congress joined with the administration in creating an apparent groundswell for such a decisive expansion.

This month's budget proposal shows just how hard such an expansion will be to sustain. Clinton himself thoroughly grasps the strategic importance of science to the country (as he grasps every issue he is briefed on) but it is not a gut issue for him, in the manner of health care, adult literacy or education. He is not going to take a strong lead on the issue - and neither is Congress. Although various influential senators and congressmen are strongly attached to the science programmes that fall under their jurisdiction, the real leadership on the research issue on Capitol Hill over the past four years came from one Newt Gingrich, who resigned as Speaker of the House of Representatives last November.

It was Gingrich, for whom scientific research was one of the few legitimate tasks of the federal government, who decreed that appropriators should find the money to support biomedical research and other university research. This gave sympathetic committee chairmen the green light for last year's massive 15.6 per cent increase at NIH and for them to treat NSF's budget request more generously than in the past.

This year, the health-research lobby will obtain more for NIH from Congress (for which Clinton will shamelessly claim credit), but probably not the 15 per cent that it is seeking. The lobby's case is undermined by its overambitious objective of doubling the NIH budget to \$25 billion over the period 1998-2003 - an expansion that raises far too many unanswered questions. Does the talent exist to justify such a rapid expansion? Can NIH be relied upon to manage such an expansion properly? And what is the point of expanding at a rate that cannot be sustained in the longer term?

Given Congress's propensity to look after NIH, however, the community's first concern should be with the rest of the science budget. The NSF figure looks good, but most of it is for yet another new computing initiative; the NSF directorates, the workhorses of high-quality university science in the United States, remain more or less at level funding, as do the best programmes at NASA, DoE and elsewhere. If this administration were to follow through on its own science policy (see Science in the National Interest, OSTP, 1994) — dealing decisively with waste and politically motivated programmes in the federal government's oversized network of laboratories, and redirecting resources towards peer-reviewed, extramural basic research — these programmes could be sensibly expanded, at modest cost.

\section{What's up, postdoc?}

\section{A survey of junior researchers in Europe shows a moderately satisfactory situation, but room for improvement.}

$D$ ostdoctoral workers, as any research supervisor knows, tend to be a stoical bunch. Overworked, undervalued and badly paid as they may be, the dominant picture that emerges from a survey of postdocs in Europe, commissioned jointly by Nature and the European Science Foundation, is that most seem prepared to accept their fate with little complaint (see page 640). As this survey reveals — and personal experience alone can testify - there are of course exceptions, both individually and geographically. But most seem relatively happy with their lot, accepting the drawbacks as, hopefully, a rite of passage.

Yet the survey also gives several causes for concern. One is the way that the experiences of postdocs vary widely across Europe, for example in the adequacy of research resources or levels of pay. This is not just a reflection of levels of economic development; it also reveals the level of commitment that governments are prepared to make towards their researchers of the future. On this, the survey should give food for thought to those in the south of Europe in particular.

For those in the north, the issues are slightly different. Here, postdocs seem to be relatively well resourced and enjoy a good working environment - one reason for the south-to-north 'brain drain' in Europe that is itself a source of concern. But, as a separate news story indicates (see page 635), they are less prepared to accept the financial sacrifices that becoming a postgraduate student requires, particularly given the insecurity in their long-term career prospects. Here, the urgent need is to find ways of incorporating postgraduate students into a well-managed professional structure. Our survey reveals some of the issues that such efforts need to address. 